\title{
Factors Affecting Tourism Marketing Demand; - Evidence from Ethiopia wildlife conservation authority and Bale Mountain National park; Ethiopia
}

\author{
Addisu Bekele Demie \\ Lecturer, College of Business and Economics: Mada Walabu University \\ DOI: $10.29322 /$ IJSRP.10.02.2020.p9833 \\ http://dx.doi.org/10.29322/IJSRP.10.02.2020.p9833
}

\begin{abstract}
The study was conducted to assess the Factors Affecting Tourism Marketing Demand in the case of Bale Mountain National Park. The main objective of the study is investigating factors affecting tourism marketing demand: the case of Bale mountain national park. The sample respondents were selected using Convenience sampling technique from non-probability sampling. For the sake of achieving the objectives of this study, administered schedule were analyzed using statistical analysis both descriptive and inferential analysis. The information gathered through schedule from a sample of 220 tourists (domestic and international) and structured interviews were conducted with 8 workers of the park and analyzed using descriptive narrations. Regression and correlation analyses are also applied for the study. The findings indicate that poor image creation, lack of proper promotion of tourist attraction, inadequate infrastructure to and inside the destination, problem of safety and security, political risk, and seasonality nature of tourism demand are factors influencing tourism marketing demand. Based on findings, improving tourism infrastructure, Building institutional capacity and developing community based ecotourism are some of the recommendation forwarded.
\end{abstract}

Index Terms- Tourism marketing, Tourism marketing demand, Bale mountain national park, Ecotourism

\section{BACKGROUND OF THE STUDY}

$\mathrm{T}$ ourism is one of the largest and rapidly growing industries in the world. Demand for international tourism remained robust in 2016 despite challenges. International tourist arrivals grew by $3.9 \%$ to reach a total of 1,235 million, and 46 million more tourist travelled internationally last year compared to 2015. 2016 was the seventh consecutive year of sustained growth following the 2009 global economic and financial crisis. As a result, 300 million more international tourists travelled the world in 2016 as compared to the pre-crisis record in 2008. The tourism has shown extraordinary strength and resilience in recent years, despite many challenges, particularly those related to safety and security (UNWTO, 2016). Tourism marketing is a process of interaction between suppliers and tourists that goods and services of tourism exchange in a specific environment of this industry (Ghadiri M. et al., 2012). Tourism marketing has been created due to the nature of tourists' demand and the specific characteristics of the suppliers' activities. Supply and demand in this industry has its own features and distinguishes it from other industries (Middleton et al., 2009). Community based ecotourism (CBET) is believed to be an important force that contributes to the war against poverty (the international ecotourism society (TIES), 2000). Ethiopia is one of suitable place for tourism attraction in that it needs to be competitive in attracting tourist and need to have appropriate marketing strategy in how to market its tourism potentials (Asmamaw \& Verma, 2013). The nature of tourism in Bale mountain national park (BMNP) is eco-tourism in nature and it is one of the interesting tourism places in Ethiopia. This make it attractive tourism place and the park have unique attractive natural resources. Despite this fact the park is unable to attract more tourists and fail to generate sufficient benefits which are match with its greatest tourism potential. Thus, this study is focus on investigating factors affecting tourism marketing demand in Bale mountain national park.

\section{StATEMENT OF THE PROBLEM}

Ethiopia is a land of plentiful, remarkable and magnificent tourism attractions. The country with its distinct and tremendous wealth of cultural, natural and historic tourism resources has huge potential of earning a great deal of benefits. However the country possesses an abundance of tourist attractions, yet tourism infrastructure is at its infancy; tourist products are poorly maintained; access to tourist products are difficult and can be inappropriately expensive; there is a lack of promotion to attract tourists to the country. In Ethiopia currently the majority of tourism is primarily cultural and historical. As recognized by National Biodiversity Strategy and Action Plan (NBSAP) (2004) environmental and wildlife tourism has enormous potential to contribute to ongoing tourism growth for generating untapped economic benefit. However, the problem is to recognize this tourism potential and managing tourism development to best benefit of the country.

Bale mountain national park (BMNP) is one of the interesting tourist attractive places in Ethiopia. Without question, it is a place of outstanding beauty and rich with attractive topography, birds and mammals. The park has unique untapped attractive natural resources. Based on preliminary assessment, lack of tourism related infrastructure, lack of consistent tourism strategy and policy, lack of tourism safety and lack of tourism 
diversification, tourist products are poorly maintained and lack of marketing are among the problem identified that hinder tourism attraction to function to its best.

By taking into account the above major problems, the researchers organized those factors that affect tourism marketing demand into four major factors: tourism product mix component, political issues, and government support and seasonality factors. There is no pre-conducted research on the study area regarding factors affect tourism marketing demand by taking these gaps into consideration, thus researchers intends to assess the factors affecting tourism marketing demand in the case of Bale mountain national park.

\section{OBJECTIVES OF THE STUDY}

The overall objective of this study is to assess factors affecting tourism marketing demand. The specific objectives of the study include:

- To assess tourism product mix component effect on tourism marketing demand.

- To assess the effect of political instability on tourism marketing demand.

- To assess the effect of government support on tourism marketing demand.

- To examine the effect of seasonality on tourism marketing demand.

\section{MATERIALS AND METHODS}

This study adopted both descriptive and exploratory type of research design. Both quantitative and qualitative approaches were simultaneously used. Of the several techniques used for data collection survey was employed, as the most appropriate technique to gather data for this study. The data were obtained by using structured interview and administered schedule distributed to sample respondent. The research design is cross sectional when we see in time aspect. The study is about assessing the factors affecting tourism marketing demand in case of bale mountain national park In order to meet this objective, descriptive research was employed.

Primary and secondary were used, and primary data was collected through self-administered structured interview and through schedule; which comprises both open ended and close ended questions that was filled up by recruited and trained enumerators under the close supervision of the researchers. The Characteristics of Sample Respondents total population for this study include tourists (international and domestic) 220 respondents and the researcher select them by using convenience sampling technique at the time of data collection and purposely selected 8 workers of the park to meet the overall objectives of the study.

The schedules were designed in English version Items in the schedule were checked for the reliability using Cronbach's alpha. Cronbach's alpha values for all items under each constructs were checked, minimum of 0.7 were obtained, and thus the literature considers this value acceptable. The instrument was also checked for its validity based on expert judgment. Variables in the study were measured by using a five- point Likert - type scale ranging from strongly disagree (1) to strongly agree (5). On the other hand, the researchers collected the qualitative data through structured interviews with managers and worker of Bale mountain national park.

For the analysis, Multiple Linear Regression Analysis method was used to test the hypothesized relationships between tourism marketing demand and the four factors. The assumptions of multiple regressions such as linearity, independence of residuals, and absence of Multicollinearity (Hair et al., 2014) were checked before running the regression models.

\section{RESULTS AND DISCUSSION}

To achieve the objective of the research, 246 sample respondents were selected from both domestic and international tourists of the park using cochran (1977)n $=\left(\frac{\mathrm{z}}{\mathrm{e}}\right)^{2} \mathrm{pq}$ sample size determination A total of 246 question were distributed to the potential respondents and a total of 220 were completed properly and were used for data interpretation. Out of this, 10 sets of questioners were considered unusable because they were not properly filled by the enumerators, while the reaming 16 of the questioners were not filled totally because of unwillingness of tourist. Therefore, only 220 usable sets of collected questioners were used for the data analysis. The response rate was $(89.43$ percent).

This section starts with description of sample respondents and descriptive analysis of the factors affecting tourism marketing demand;- the case of Bale mountains national park. It is followed by the regression analysis with the aim of finding out the relationship between the dependent and independent variables.

Table 1: demographic, social and economic characteristic of the respondent

\begin{tabular}{|l|l|l|l|l|l|l|l|l|}
\hline \multirow{2}{*}{$\begin{array}{l}\text { Type of } \\
\text { variable }\end{array}$} & \multicolumn{3}{|l|}{ International tourist } & \multicolumn{2}{l|}{ Domestic } & \multicolumn{2}{l|}{ Total } \\
\cline { 3 - 9 } & Category & $\begin{array}{l}\text { Freque } \\
\text { ncy }\end{array}$ & $\begin{array}{l}\text { Percent } \\
\text { age }\end{array}$ & $\begin{array}{l}\text { Freque } \\
\text { ncy }\end{array}$ & $\begin{array}{l}\text { percen } \\
\text { tage }\end{array}$ & $\begin{array}{l}\text { Freque } \\
\text { ncy }\end{array}$ & Percent \\
\hline \multirow{2}{*}{$\begin{array}{l}\text { Gender of } \\
\text { respondent }\end{array}$} & Male & 98 & 66.7 & 47 & 64.4 & 145 & 65.9 \\
\cline { 3 - 10 } & Female & 49 & 33.3 & 26 & 35.6 & 75 & 100 \\
\cline { 3 - 10 } & Total & $21-30$ & $\mathbf{1 4 7}$ & $\mathbf{1 0 0}$ & $\mathbf{7 3}$ & $\mathbf{1 0 0}$ & $\mathbf{2 2 0}$ & \\
\hline \multirow{2}{*}{$\begin{array}{l}\text { Age of } \\
\text { respondent }\end{array}$} & $31-40$ & 3 & 2.0 & 16 & 21.9 & 19 & 8.6 \\
\cline { 3 - 10 } & & 54 & 36.7 & 18 & 24.7 & 72 & 41.4 \\
\hline
\end{tabular}




\begin{tabular}{|c|c|c|c|c|c|c|c|c|}
\hline & & $41-50$ & 90 & 61.2 & 27 & 37.0 & 117 & 94.5 \\
\hline & & Above 50 & & & 12 & 16.4 & 12 & 100 \\
\hline & & Total & 147 & 100 & 73 & 100 & 220 & \\
\hline 3 & \multirow{5}{*}{$\begin{array}{l}\text { Marital status } \\
\text { of the } \\
\text { respondent }\end{array}$} & Married & 113 & 76.9 & 56 & 76.7 & 169 & 76.8 \\
\hline & & Single & 11 & 7.5 & 6 & 8.2 & 17 & 84.5 \\
\hline & & Widow & 10 & 6.8 & 9 & 12.3 & 19 & 93.2 \\
\hline & & Divorced & 13 & 8.8 & 2 & 2.7 & 15 & 100 \\
\hline & & Total & 147 & 100 & 73 & 100 & 220 & \\
\hline \multirow[t]{6}{*}{4} & \multirow{5}{*}{$\begin{array}{l}\text { Education } \\
\text { level of the } \\
\text { respondent }\end{array}$} & Certificate & 2 & 1.4 & 2 & 2.7 & 4 & 1.8 \\
\hline & & Diploma & 29 & 19.7 & 16 & 21.9 & 45 & 22.3 \\
\hline & & Bachelor degree & 71 & 48.3 & 38 & 52.1 & 109 & 71.8 \\
\hline & & Master degree & 44 & 29.9 & 17 & 23.3 & 61 & 99.5 \\
\hline & & PHD and above & 1 & .7 & - & - & 1 & 100 \\
\hline & & Total & 147 & 100 & & & 220 & \\
\hline \multirow[t]{5}{*}{5} & \multirow{5}{*}{$\begin{array}{l}\text { Income per } \\
\text { year of the } \\
\text { respondent }\end{array}$} & Below $6000 \$$ & - & - & 20 & 27.4 & 20 & .9 .1 \\
\hline & & $6001-12000$ & 33 & 22.4 & 34 & 46.6 & 67 & 39.5 \\
\hline & & $12001-18000$ & 60 & 40.8 & 17 & 23.3 & 77 & 74.5 \\
\hline & & $18001-24000$ & 54 & 36.7 & 2 & 2.7 & 56 & 100 \\
\hline & & Total & 147 & 100 & 73 & 100 & 220 & \\
\hline \multirow[t]{6}{*}{6} & \multirow{6}{*}{$\begin{array}{l}\text { Expense per } \\
\text { day }\end{array}$} & $300-600$ & 15 & 10 & 36 & 49.3 & - & - \\
\hline & & $601-900$ & 34 & 23.1 & 25 & 34.2 & 4 & 1.8 \\
\hline & & $901-1200$ & 70 & 47.6 & 11 & 15.1 & 56 & 27.3 \\
\hline & & $1201-1500$ & 28 & 19 & 1 & 1.4 & 104 & 74.3 \\
\hline & & 1501 and above & - & - & - & - & 56 & 100 \\
\hline & & Total & 147 & 100 & 73 & 100 & 220 & \\
\hline \multirow[t]{4}{*}{7} & \multirow{4}{*}{$\begin{array}{l}\text { How long } \\
\text { you will stay } \\
\text { at the park }\end{array}$} & 2day & 20 & 13.6 & 38 & 52.1 & & \\
\hline & & 3 day & 53 & 36.1 & 24 & 32.9 & 96 & 43.6 \\
\hline & & 4 day and above & 74 & 50.3 & 11 & 15.1 & 124 & 100 \\
\hline & & Total & 147 & 100 & 73 & 100 & 220 & \\
\hline
\end{tabular}

Source:- survey questionnaires, 2017

Major group of respondents gender for both domestic and international tourist were male $(65.9 \% \%)$ and follows by female $(34.1 \%)$. Therefore, more respondents to the sample were males. the respondents' age for both domestic and international were between the ages of 41-50 years, which constitute (53.2\%), and the minimum group of respondent age falls in the age interval of above 51 years covers $(5.5 \%)$ respectively. This implies that the majority groups of tourist visiting the destination age was fall under age of $41-50$. The marital status was married (76.4\%). It could be concluded that majority group of tourist visiting the destination are married. As it can be seen from the above table the major groups of respondents hold Bachelor's Degree holder (49.5\%). Here, one can say that majority of both domestic and international tourist visiting the park hold Bachelor degree and this indicate that most of the tourists are educated. Regarding the Income is falls between the intervals of 6001- 12000\$ (46.6\%). thus more of the visitors have medium income per year On the other hand the finding reveals that daily expense of the respondents, 300- $600(49.3 \%)$. This indicates that income per year of the respondent and their daily expense has a relation. Major groups of the tourists are stay 4 day and above (38.6\%). thus the main thing here is that increasing the stay time of tourists helps the destination to generate more revenue.

\section{Descriptive Analysis of the Study Variables}

This part of the analysis is made based on survey schedule gathered from 220 tourists of Bale mountain national park using 5-point Likert's scale. The study has four independent variables: tourism product mix component, political issues, government support and seasonality factors; and a tourism marketing demand as dependent variable. For a consistent interpretation of descriptive analysis, the following criterion is used.

Table 2: Five-Scaled Likert's Criterion

\begin{tabular}{|l|l|l|}
\hline No. & Mean Range & Response Options \\
\hline 1 & {$[1.00,1.80)$} & Strongly Disagree \\
\hline
\end{tabular}


Source: Al-Sayaad et al. (2006)

\begin{tabular}{|l|l|l|}
\hline 2 & {$[1.80,2.60)$} & Disagree \\
\hline 3 & {$[2.60,3.40)$} & Neutral \\
\hline 4 & {$[3.40,4.20)$} & Agree \\
\hline 5 & {$[4.20,5.00]$} & Strongly Agree \\
\hline
\end{tabular}

Table 3: Descriptive statistic of Tourism product mix component

\begin{tabular}{|l|l|l|l|l|l|l|}
\hline \multicolumn{1}{|c|}{ Scale item } & N & Min & Max & Mean & Std. Dev. & level \\
\hline there are easy access of transportation inside the park & 220 & 1.00 & 5.00 & 2.2909 & 1.23011 & Disagree \\
\hline proper natural resource conservation practice & 220 & 2.00 & 5.00 & 3.3091 & 1.47271 & Neutral \\
\hline availability of good Accommodations & 220 & 1.00 & 5.00 & 2.1591 & 1.17320 & Disagree \\
\hline internet infrastructure & 220 & 1.00 & 5.00 & 2.3273 & 1.24313 & Disagree \\
\hline Activities (eg. camping, etc.) & 220 & 1.00 & 5.00 & 2.5773 & 1.37772 & Neutral \\
\hline the park are full Varity endemic plant type & 220 & 1.00 & 5.00 & 3.4636 & 1.1 .53603 & Agree \\
\hline I am impressed in BMNP attraction and it environment & 220 & 1.00 & 5.00 & 3.7955 & 1.47087 & Agree \\
\hline $\begin{array}{l}\text { The tour operators offer good service for me } \\
\text { Valid N (listwise) }\end{array}$ & 220 & 1.00 & 5.00 & 3.7182 & 1.44065 & Agree \\
\hline
\end{tabular}

Source: - survey questionnaires, 2017

As can be seen from the above table the access of transportation inside the park, Accommodations found in bale are convenient, comfortable, and safe for my consumption and there are good internet infrastructure at the tourist site (Bale mountain national park) which has the mean value $2.2909,2.1591$ and 2.3273 respectively. The mean value falls under the response scale of disagree. So, it implies that the transportation, the accommodations infrastructure found in bale are not convenient, comfortable, and safe and there is lack good communication infrastructure in Bale mountain national park. As the Findings indicates The Park are full of Variety endemic plant type, I am impressed in BMNP attraction and it environment, which has the mean value 3.4636 and 3.7955 respectively. The mean value falls on the response scale of agree. This implies that the park has variety endemic plant type and the visitor is impressed by attraction and its environment.

The responses of interview also support the findings through schedule. Bale mountain national park have attractive untapped natural gift with endemic flora and fauna which are endemic to our country and to the globe. Ethiopia have enormous tourism potential but there are small number of tourists arrival and the sector does not generate sufficient revenue for the country economy, because of lack of infrastructural facilities such as lack of camp site for tourist in the park, lack of communication infrastructure, accommodation problem, lack of road and other facilities, stay time of tourists are very low these reduce the income generated from tourism marketing of the sector.

Table 4: descriptive statistic of Political issues

\begin{tabular}{|c|c|c|c|c|c|c|}
\hline Scale item & $\mathbf{N}$ & Min & Max & Mean & Std. Dev. & level \\
\hline There is no Security problem in Bale & 220 & 1.00 & 5.00 & 2.4136 & 1.00082 & D/agree \\
\hline There is no any political risk affects my visiting & 220 & 1.00 & 5.00 & 2.5273 & 1.06595 & D/agree \\
\hline No safety problem face me & 220 & 1.00 & 5.00 & 2.3182 & 1.05495 & D/agree \\
\hline $\begin{array}{l}\text { The presence of good security protection makes me more confidential } \\
\text { to visit the destination }\end{array}$ & 220 & 2.00 & 5.00 & 4.2772 & .83334 & Agree \\
\hline There are political protests when I am visiting the park & 220 & 1.00 & 5.00 & 3.7136 & 1.12862 & Agree \\
\hline $\begin{array}{l}\text { My major consideration in travelling decision to visit any foreign } \\
\text { destination country's political stability }\end{array}$ & 220 & 1.00 & 5.00 & 4.2500 & .90471 & Agree \\
\hline The presence of political stability initiates me to visit & 220 & 2.00 & 5.00 & 4.2491 & .84462 & Agree \\
\hline $\begin{array}{l}\text { the political stability has great support for tourism income generation } \\
\text { capacity (BMNP) } \\
\text { Valid N (listwise) }\end{array}$ & 220 & 2.00 & 5.00 & 4.3864 & .71564 & Agree \\
\hline
\end{tabular}

Source: survey questinarries, 2017 
As the table above depicted that the scale item There is no Security problem in bale when I am visiting the park, There is no any political risk affects my visiting decision of the park, and No safety problem face me when I am traveling to BMNP which has the mean value $2.5273,2.4136$ and 2.3182 respectively. This implies that there are security and safety problem which influences the tourist's visitation and the tourists are fair the risk of political issues of the country. Therefore, the political instability of the country has great effect on the development of tourism marketing in general as well as the increasing number of tourists' arrival of the park in particular.

As the table indicates that the presence of good security protection makes me more confidential to visit the destination, There are political strikes or protests when I am visiting the park in which it affects my stay time at the tourist site and political stability as major consideration in travelling decision to visit any foreign tourist destination which has the mean value 4.2773, 3.7136 and 4.2500 respectively. The mean value falls under the response scale of strongly agree. This implies that the presence of good security protection, absence of political protest and the presence of political stability have great role in attracting more visitor to the park. As the table above depict that the scale item "The presence of political stability initiates me to visit different tourism sites which have special natural gifts like Bale mountain national park" and" the political stability has great support for tourism income generation capacity (Bale mountain national park).", which has the mean value 4.2591 and 4.3864 respectively. The mean value falls under the response scale of strongly agree. This implies that the presence of political stability initiate the tourist who visiting different destination and it has great role in increase the income obtained from the tourism marketing.

Table 5: Descriptive statistics of government support

\begin{tabular}{|c|c|c|c|c|c|c|}
\hline Scale item government support & $\mathbf{N}$ & Min & Max & Mean & Std. Dev. & Level \\
\hline promotion made by ministry about the park & 220 & 1.00 & 5.00 & 2.200 & 1.24453 & Disagree \\
\hline giving good information at ministry level & 220 & 1.00 & 5.00 & 2.3091 & 1.30853 & Disagree \\
\hline The coordination between the park and the community are good & 220 & 1.00 & 5.00 & 2.3364 & 1.33295 & Disagree \\
\hline $\begin{array}{l}\text { There is good professional compliant handling system at the } \\
\text { park }\end{array}$ & 220 & 1.00 & 5.00 & 2.1409 & 1.22126 & Disagree \\
\hline The country create proper image & 220 & 1.00 & 5.00 & 2.2182 & 1.20790 & Disagree \\
\hline
\end{tabular}

Source; survey questionnaires, 2017

As the table above depict that the scale item "I am decide to visit the park after I was see the promotion made by ministry about the park" and "Ministry of culture and tourism help me by giving good information about the park" which has the mean value 2.200 and 2.3091 respectively. This shows that there are week promotional activities made by the government and poor information coordination at the ministry level. Furthermore the table indicates that the scale item the coordination between the park and the community are good and there is good professional compliant handling system at the park which has the mean value 2.3364 and 2.1409 respectively. This implies that poor coordination with stake holders and poor compliant handling mechanism in the park. These create poor tourism marketing and reduce the income generation of tourist destination.

As the table above depict that the scale item The country create proper image of tourism destination like Bale mountain national park and The country create awareness about her tourists attraction at national and international level", which has the mean value 2.2182 and 2.2045 with respectively. The mean value falls under the response scale of disagree. This implies that there are poor image of the country, poor awareness creation and it needs to have improved in creating awareness about the tourism potential of the country in general and the tourism destination in particular.

As the response of interview also support the finding of questionnaires, that support of government are very low in terms of financial support, promotion, in human resource development, poor recognition for tourism marketing, lack support in prevention of natural resource and in reducing the human encroachment in the park because human encroachment affect the eco-system of wildlife, it also create bad image in the mind of the tourist when they see human in the park and the human encroachment create immigration of wildlife to the neighbor country.

Table 6: Descriptive statistics of seasonality effect

\begin{tabular}{|l|l|l|l|l|l|l|}
\hline \multicolumn{1}{|c|}{ Scale items } & $\mathbf{N}$ & Min & Max & Mean & Std. Dev. & Level \\
\hline $\begin{array}{l}\text { I am visiting Bale mountain national park because I am on } \\
\text { vacation }\end{array}$ & 220 & 1.00 & 5.00 & 3.4818 & 1.44445 & Agree \\
\hline $\begin{array}{l}\text { Promoting the destination attractiveness during the off } \\
\text { season }\end{array}$ & 220 & 1.00 & 5.00 & 3.5500 & 1.43417 & Agree \\
\hline $\begin{array}{l}\text { The temporal imbalance tourism phenomenon } \\
\text { I am select favorable season to visit the park }\end{array}$ & 220 & 1.00 & 5.00 & 3.4273 & 1.41395 & Agree \\
\hline The off season effect on employment & 220 & 1.00 & 5.00 & 3.4773 & 1.31185 & Agree \\
\hline
\end{tabular}




\begin{tabular}{|l|l|l|l|l|l|l|}
\hline Climatic condition & 220 & 1.00 & 5.00 & 3.5591 & 1.37198 & Agree \\
\hline Presence of the events/festivals & 220 & 1.00 & 5.00 & 3.3409 & 1.50711 & Neutral \\
\hline Valid N (listwise) & 220 & & & & & \\
\hline
\end{tabular}

Source; survey questionnaires, 2017

Finding from table, indicate that scale item I am visiting Bale mountain national park because I am on vacation, I am select favorable season to visit the park, promoting the destination attractiveness has great role in improving the tourism demand, The temporal imbalance of the phenomenon of tourism, off season of tourism creating unemployment problem, and Climatic condition affects tourist decision to visit the destination" which has the mean value which has the mean value $3.4818,3.4773,3.5500,3.4273$, 3.5773 and 3.5591 respectively. The mean value falls under the response scale of agree. This implies that tourists' visiting the park is adjusting their visitation program when they are on vacation, selecting favorable season for visiting, promotion, temporal imbalance of tourism activity, climatic change and off season affect tourism marketing demand.

Table 7: descriptive statistics of tourism marketing demand

\begin{tabular}{|l|l|l|l|l|l|l|}
\hline Scale item & N & Min & Max & Mean & Std. Dev & Level \\
\hline Distance from the center & 220 & 1.00 & 5.00 & 4.0864 & 1.08405 & Agree \\
\hline there are no safety and security problem & 220 & 1.00 & 5.00 & 1.8182 & .77261 & S/disagree \\
\hline Promotion made by government & 220 & 1.00 & 5.00 & 2.7773 & 1.34145 & Neutral \\
\hline Temporal change fluctuation of tourism demand & 220 & 1.00 & 5.00 & 3.3273 & 1.39542 & Disagree \\
\hline Valid N (listwise) & 220 & & & & & \\
\hline
\end{tabular}

Source: survey questionnaires, 2017

As the table above depict that "Tourism marketing of the park are affected by it location form the center" which has the mean value 4.0864. The mean value falls on the response scale of agree. This implies that the location of the destination affect their visitation and stay time. Therefore, access good infrastructure has great role in the development of tourism marketing of the country in general and of the destination in particular.

Furthermore the table above, indicate that safety and security problem in bale mountain national park", which has the mean value 1.8182 . The mean value fall under the response scale of disagree. This indicates that there are some safeties and security problem when they are visiting the destination and these problems affect the tourism demand.

\section{Results of Inferential Statistics}

In this section, the results of inferential statistics are presented. In order to address the objectives of the study, Pearson's Product Moment Correlation Coefficient and regression analyses were performed. With the aid of these statistical techniques, conclusions are drawn and decisions are made with respect to the research hypothesis.

\section{Correlation coefficient}

Table 8: relationship between independent variable and tourism marketing demand

\begin{tabular}{|c|c|c|c|c|c|c|c|c|}
\hline \multirow{2}{*}{\multicolumn{2}{|c|}{ Model }} & \multicolumn{2}{|c|}{$\begin{array}{l}\text { Unstandardized } \\
\text { Coefficients }\end{array}$} & $\begin{array}{l}\text { Standardized } \\
\text { Coefficients }\end{array}$ & \multirow[t]{2}{*}{$T$} & \multirow[t]{2}{*}{ Sig. } & \multicolumn{2}{|c|}{ Collinearity Statistics } \\
\hline & & B & Std. Error & Beta & & & Tolerance & VIF \\
\hline \multirow{5}{*}{1} & (Constant) & 2.904 & .375 & & 7.748 & .000 & & \\
\hline & TP & .324 & .048 & .401 & 6.777 & .000 & .482 & 2.073 \\
\hline & PI & -.166 & .080 & -.093 & -2.076 & .039 & .839 & 1.192 \\
\hline & GS & .196 & .043 & .222 & 4.529 & .000 & .704 & 1.421 \\
\hline & SF & -.203 & .043 & -.270 & -4.695 & .000 & .511 & 1.955 \\
\hline
\end{tabular}

a. Dependent Variable: TM

Source: survey questionnaires, 2017

As it is clearly indicated in the above table 8 , a strong positive relationship was found between tourism product mix component and tourism marketing demand $(\mathrm{r}=.730, \mathrm{p}<.01)$, seasonality and tourism marketing demand has moderate and inverse relationship $(r=-.675, \mathrm{p}<.01)$, that means, as the effect of seasonality decline, tourism marketing demand was increase.
Government support and tourism marketing demand has moderate and direct relationship $(\mathrm{r}=.573, \mathrm{p}<0.01)$, and political factor and tourism marketing demand has negative and weak correlation $(\mathrm{r}=$ $-.377, \mathrm{P}<0.05)$ which are statistically significant at $95 \%$ confidence level. 
This implies that at a $1 \%$ level of significance it was found that the tourism product mix, political issues, government support and seasonality factors have a significant relationship with tourism marketing demand in the study area.

\section{Regression analysis}

The regression analysis can be determined whether the independent variables explain a significant variation in the dependent variable, including whether a relationship exists. Regression analysis also determine how much of the variation in the dependent variable can be explained by the independent variables. That is, the strength of the relationship. In regression analysis, this is measured by Adjusted R Square, R².
The dependent variable for this study is Tourism demand whereas the four independent variables are TP, PI, GS and SF with regard tourism marketing of Bale mountain national park. Tourism marketing of the destination can be measured by the use of number of arrivals (Tourism marketing demand).

Generally, the study tested four major assumptions such as Normality, Multicollinearity, Linearity, and Homoscedasticity that must be fulfilled to analyze data using multiple linear regression models. Since all the four assumptions were not violated, the researcher examined the data collected by the schedule using multiple regression models.

Table 9: ANOVA (Analysis of Variance)

\begin{tabular}{|c|c|c|c|c|c|c|}
\hline Model & & Sum of Squares & Df & Mean Square & $\mathrm{F}$ & Sig. \\
\hline \multirow{3}{*}{1} & Regression & 76.608 & 4 & 19.152 & 94.352 & $.000^{\mathrm{b}}$ \\
\hline & Residual & 43.641 & 215 & .203 & & \\
\hline & Total & 120.249 & 219 & & & \\
\hline
\end{tabular}

Table 10: model summary

\begin{tabular}{|l|l|l|l|l|}
\hline Model & R & R Square & Adjusted R Square & Std. Error of the Estimate \\
\hline 1 & $.798^{\mathrm{a}}$ & .637 & .63 & .45054 \\
\hline
\end{tabular}

a. Predictors: (Constant), TP, PI, GS, SF

Source : survey questionnaires, 2017

From table 10 above, " $R$ " has a score of .637. It is a multiple correlation coefficient between dependent and independent variables of the study. " $R$ " represents the value of the multiple correlation coefficients between the predictors and the outcome (Field, 2005). The results show that the coefficient of multiple determinations $\left(\mathrm{R}^{2}\right)$ is .637 and adjusted $\mathrm{R}^{2}$ is .63 indicating the regression model is good fit. It reveals that about 63.0 percent of the variation in dependent variable So, there are other factors that are not incorporated in the model to explain tourism marketing demand of Bale Mountain National park.

Table 11: Coefficients' Table on Multiple Regression of the Research Model

\begin{tabular}{|c|c|c|c|c|c|c|c|c|}
\hline \multirow{2}{*}{\multicolumn{2}{|c|}{ Model }} & \multicolumn{2}{|c|}{$\begin{array}{l}\text { Unstandardized } \\
\text { Coefficients }\end{array}$} & $\begin{array}{l}\text { Standardized } \\
\text { Coefficients }\end{array}$ & \multirow[t]{2}{*}{$\mathrm{T}$} & \multirow[t]{2}{*}{ Sig. } & \multicolumn{2}{|c|}{ Collinearity Statistics } \\
\hline & & B & Std. Error & Beta & & & Tolerance & VIF \\
\hline \multirow{5}{*}{1} & (Constant) & 2.904 & .375 & & 7.748 & .000 & & \\
\hline & $\mathrm{TP}$ & .324 & .048 & .401 & 6.777 & .000 & .482 & 2.073 \\
\hline & PI & -.166 & .080 & -.093 & -2.076 & .039 & .839 & 1.192 \\
\hline & GS & .196 & .043 & .222 & 4.529 & .000 & .704 & 1.421 \\
\hline & SF & -.203 & .043 & -.270 & -4.695 & .000 & .511 & 1.955 \\
\hline
\end{tabular}

b. Dependent Variable: TM

Source: survey questionnaires, 2017

Table 11: further the table shows that, all the explanatory variables included in this study significantly explain the variation of the dependent variable at 99 percent confidence level. The standardized beta coefficient column shows the contribution that an individual variable makes to the model. Accordingly, the most contributing factors for tourism marketing demand are tourism product mix with beta value of -.401 followed by seasonality factors with the value of -.270 . 


\section{CONCLUSION AND RECOMMENDATION}

The purpose of this study was to identify and examine those factors affecting tourism marketing demand. And to this end, the study sought to identify the most important factors that are behind the tourism marketing demand in the study area. As depicted by the results of descriptive statistics, tourism marketing demand in the study area is challenged by tourism product mix, political issue, and government support and seasonality factors.

As a supplement to the quantitative results, qualitative findings also show that the tourism marketing demand affected by climate condition, political instability, lack of infrastructure, promotion problem, and seasonal fluctuation.

The other factors which influence tourism marketing demand of the park are lack support from government which include the destination are registered before long time ago on tentative united nation economic, social and cultural organization (UNESCO), but not registered permanently these are because of weak government support, poor compliant handling, poor implementation of rule and regulation of government law, poor image of government officials for destination and lack of proper recognition for tourism in general. This shows that government support has great effect on tourism development in general as well as income generation of the destination tourism marketing.

The political issue are also the factors influencing demand of the destination which include the problem safety when they are visiting the park, fair security, problem of political risk and the presence of strike or protest are the main factor affecting tourism marketing demand. The declining of number of tourist arrivals are caused because of the political instability caused in the country last year and it influence strongly tourism marketing demand of the country in general and the destination in particular, for these reason most tourist which are book their visitation time of the destination and remove their plan and change to other African countries which good political stability. Thus, it does not matter how incorrect or wrong a perception of risk may be, it will influence the behavior of the tourist in exactly the same way that decisions would be affected by changes in the level of actual risk. Seasonality in tourism activity is not a particular characteristic of a single destination or country, as it is experienced in almost all countries and destinations in the world. Seasonality causes the fluctuation in tourists and visitor numbers to a destination. Therefore, some destination at certain times has more tourists and visitors than they are able to accommodate, while at other times, there are too few tourists and visitors to the region. Thus, The issues which study are focus on are effect of seasonality on tourism marketing demand and the income generation of the destination are climatic change, unemployment problem which leads to devaluation the income of the service organization serving tourist, lack of plan for off season of tourism activity, because of our country tourism activity are at its infant level and absence of remedial action for the seasonality. This phenomenon is mostly recognized as a problem to be tackled. The majority of the tourist operators dealing with the issue of seasonality identify these systematic demand fluctuations as a problem, which has to be overcome or, at least, modified and reduced in effect.

As the result of the finding show, the change in the dependent variables $\left(\mathrm{R}^{2}=.637\right)$ means that the total variation in the dependent variable (tourism marketing demand or tourist arrivals) is explained or caused by 63.7 percent of the change in all independent variables. It can be conclude that the selected variables have explain tourism marketing demand $63.7 \%$ and the rest percent are explained by other.

\section{Recommendation}

Suggestions for corrective and complementary measures to enhance the tourism marketing demand are required. Such recommendations need an in-depth analysis of the influence of different factors regarding the sector. Based on the findings and conclusions of the study, the following recommendations are forwarded.

- Improving tourism infrastructure: there are infrastructural problem inside and to the park. Therefore, it needs to reduce overall tourism infrastructural problem eg. Building camp site and lodge by communicating with investor and working by integration with all stake holders.

- Building institutional capacity: Ministry of Tourism and culture is concerning authority for tourism development in our country. Again, other institutional bodies are engaging for ecotourism development in the country. So, it is necessary to build up institutional capacity and coordination among the bodies for ecotourism development.

- Creating awareness to the local community in protecting the destination natural resource, because the involvement of human, domestic dog and cattle in the protected area reduce the quality of attraction.

- Political stability is of extreme importance to any investment, but it is of special consequence to tourism because of what is being sold: serenity, leisure, fun and comfort. These can only be successfully marketed under stable political conditions.

- As tourism is seasonal in its nature, it creates seasonal unemployment; this seasonality flow creates in efficiencies in terms of utilizing resources. Thus, tourism marketing face large negative impacts at times of sudden drop of tourism demand.

- Linkage to other types' of tourism: Ecotourism can ensure the sustainable tourism development in any country. For this reason, BMNP and our country in general should develop ecotourism inter related with other types' tourism such as, heritage tourism, education and culture tourism.

\section{REFERENCES}

[1] Al-Sayaad, J., Rabea, A., Samrah, A. (2006). Statistics for Economics and Administration Studies. Dar Hafez, Jeddah, Kingdom of Saudi Arabia.

[2] Asmamaw, D. \&Verma, A. (2013). Local Attitudes towards Environmental Conservation and Ecotourism around Bale Mountains National Park, Ethiopia. Scholarly Journal of Agricultural Science.

[3] The International Ecotourism Society, (2000). Ecotourism Statistical Fact Sheet. Retrieved October 20, 2006, from http://www.ecotourism.org/research/stats/files/stats.pdf

[4] Hair, J. F., Hult, T. M., Ringle, C. M. \& Sarstedt, M. (2014). A Primer on Partial Least Squares Structural Equation Modeling (PLS-SEM) (1st Edition). Thousand Oaks. California: SAGE Publications, Inc.

[5] Cothran,.D.A. and Cothran, C.C. (1998). "Promise or Political Risk for Mexican Tourism". Annals of Tourism Research, 25(2), 477-497.

[6] Kothari, C. R. (2004). Research Methodology: Methods and Techniques (2nd Revised Ed.). India: New Age International Publishers.

[7] Middleton, V., Fyall, A., \& Morgan, M. (2009). Marketing in travel and tourism ( 4 th ed.). $\quad$ British library cataloging in publication data. 
[8] NBSAP, (2004). National biodiversity strategy and action plan, institute of biodiversity conservation report. Addis Ababa; Ethiopia.

[9] UNWTO, (2016). World tourism barometer. Vol.15. advanced release January 2017.

[10] Ghadiri Masoom., M., Soori,F., Shafiei, Arabi,M.A. (2012). Evaluation and leveled the Effective Components in Rural Tourism Marketing with Marketing Mix (7P) (Case Study: selected

Mazandaran). Journal of Urban Management, 32, 152-139.

\section{AUTHORS}

First Author - Addisu Bekele Demie, Lecturer, College of Business and Economics: Mada Walabu University 